\title{
Identification and Physicochemical Characterization of a New Allergen from Ascaris lumbricoides
}

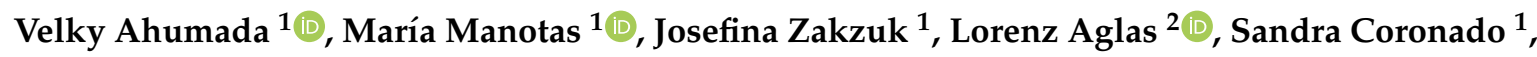

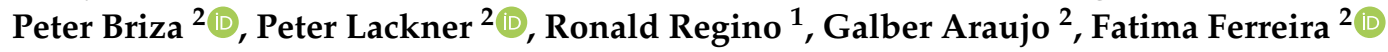 \\ and Luis Caraballo ${ }^{1, *}$ \\ 1 Institute for Immunological Research, University of Cartagena, Cartagena 130014, Colombia; \\ vahumadac@unicartagena.edu.co (V.A.); manotas.mcarolina@javeriana.edu.co (M.M.); \\ jzakzuks@unicartagena.edu.co (J.Z.); scoronador@unicartagena.edu.co (S.C.); \\ rreginol@unicartagena.edu.co (R.R.) \\ 2 Department of Biosciences, University of Salzburg, 5020 Salzburg, Austria; lorenz.aglas@sbg.ac.at (L.A.); \\ Peter.Briza@sbg.ac.at (P.B.); peter.lackner@sbg.ac.at (P.L.); galber.rodriguesaraujo@sbg.ac.at (G.A.); \\ fatima.ferreira@sbg.ac.at (F.F.) \\ * Correspondence: lcaraballog@unicartagena.edu.co; Tel.: +57-3103527373
}

Received: 1 December 2020; Accepted: 18 December 2020; Published: 21 December 2020

\begin{abstract}
To analyze the impact of Ascaris lumbricoides infection on the pathogenesis and diagnosis of allergic diseases, new allergens should be identified. We report the identification of a new Ascaris lumbricoides allergen, Asc 15 . The aim of this study was to evaluate the physicochemical and immunological features of the Asc 15 allergen. We constructed an A. lumbricoides cDNA library and Asc 15 was identified by immunoscreening. After purification, rAsc 15 was physicochemically characterized. Evaluation of its allergenic activity included determination of Immunoglobulin E (IgE) binding frequency (in two populations: 254 children and 298 all-age subjects), CD203c based-basophil activation tests (BAT) and a passive cutaneous anaphylaxis (PCA) mouse model. We found by amino acid sequence analysis that Asc 15 belongs to the SXP/RAL-2 protein family of nematodes. rAsc 15 is a monomeric protein with an alpha-helical folding. IgE sensitization to rAsc 15 was around $52 \%$ in general population; positive BAT rate was $60 \%$. rAsc 15 induced specific IgE production in mice and a positive PCA reaction. These results show that Asc 15 has structural and immunological characteristics to be considered as a new allergen from A. lumbricoides.
\end{abstract}

Keywords: Ascaris; allergen; IgE; Asc 15; cDNA-library

\section{Introduction}

The prevalence of allergic diseases has increased worldwide during the last few decades, probably depending on environmental and genetic influences. In the tropics, where allergic diseases and intestinal helminthiases are frequent [1,2], their relationships can influence the pathogenesis of both disorders. Ascaris lumbricoides infection (ascariasis) exerts a dual effect on allergic diseases such as asthma: it can increase prevalence and symptoms or diminish the allergic inflammation through immunomodulating molecules [3]. The immunostimulant effect of ascariasis has been explained by non-specific boosting of T helper 2 (Th2) immunity, direct effects of larvae migration [1,4] and cross-reactivity with house dust mite (HDM) allergens [5,6]. In addition, the existence of helminthiases has limited the use of traditional diagnostic markers of allergy (such as total and specific IgE) in the tropics, supporting the need for the detection of specific immune response. For those reasons, research on helminth/allergy interactions is of great scientific and clinical interest in both industrialized and developing countries [7]. 
So far, three allergens from Ascaris have been described, one species-specific (Asc s 1) and two cross-reactive with HDM (Asc 13 and Asc 113) [6,8-10]; however, the whole extract has at least nine additional IgE binding components [11]. Since Ascaris induces strong IgE responses even from an early age [12], other antigens could be potential allergens.

On the process of characterizing new allergens, it has been realized that allergenicity (IgE induction and binding capacity) is not enough to demonstrate the whole allergenic activity; other tests that confirm the involvement of candidate molecules in the inflammatory allergic reaction are necessary [13]. Furthermore, the physicochemical characterization of the molecule will help to understand both, biological and immunological properties. In connection with our previous work about $A$. lumbricoides allergen characterization [6,8], in the present work we constructed an A. lumbricoides cDNA library, isolated and expressed a new IgE-binding molecule (Asc 15 ), identified its native counterpart in a natural source, analyzed its physicochemical attributes with a focus on aggregation behavior, ligand binding properties, secondary structural elements and bioinformatics analysis, and investigated the IgE-binding frequency and allergenic activity induced by Asc 15 in humans and in a mouse model of a passive cutaneous anaphylaxis (PCA). As a result, we identified and characterized a new A. lumbricoides allergen.

\section{Results}

\subsection{Asc 15 Belongs to the SXP/RAL-2 Protein Family}

Immunoscreening of the A. lumbricoides cDNA expression library with patients' sera detected three IgE-positive spots. The 3 clones were coding the same sequence that was submitted to the GenBank database under accession number MN275230; the allergen was designated as Asc 15 by the International Union of Immunological Societies (IUIS) Nomenclature Committee. Sequence analysis showed that Asc 15 belongs to SXP/RAL-2 protein family. SXP motif 1 and SXP motif 2 are shown in the sequence of Asc 15 (Figure 1). When compared with sequences in databases, similarities were found with other nematode proteins, for example As16 from Ascaris suum, Ag2 from Baylisascaris schroederi, As14 from A. suum, and nematode infection markers such as SPX antigens from Brugia malayi and Wuchereria bancrofti. It was of great interest for us that there were three Anisakis simplex allergens in the same family: Ani s 5, Ani s 8 and Ani s 9. Since Ani s 5 is the only member of this protein family that has been physicochemically characterized and its 3D structure resolved by nuclear magnetic resonance (NMR, Protein Data Bank (PDB) entry 2MAR) [14], and considering the percent of identity between the two proteins (53\%), it was very helpful for addressing the physicochemical characterization of Asc 15 . 

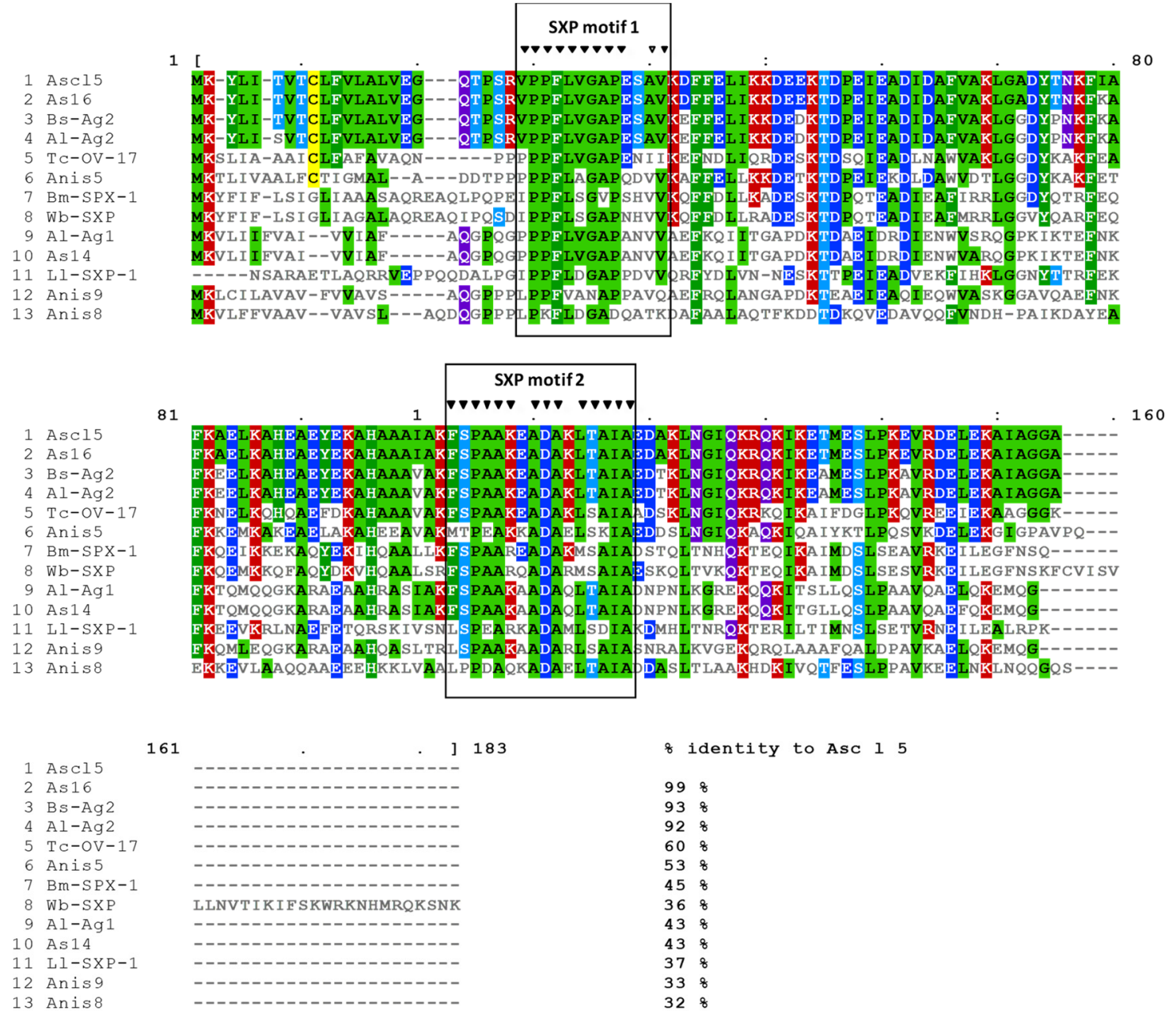

Figure 1. Amino acid sequence alignment of Asc 15 with other members of the SXP/RAL-2 protein family. Each protein sequence is preceded by its name. Database entry code as follow: As16 from Ascaris suum: BAC66614.1. Ag2 from Baylisascaris schroederi: ACJ03762.1. Ag2 from Ascaris lumbricoides: ADB45852.1. OV-17 antigen from Toxocara canis: KHN84076.1. Ani s 5 from Anisakis simplex: BAF43534.1. SPX-1 from Brugia malayi: AAA27864.1. SXP antigen from Wuchereria bancrofti: AAC70783.1. Ag1 from Ascaris lumbricoides: ACJ03764.1. As14 from Ascaris suum: BAB67769.1. SXP-1 protein from Loa loa: AAG09181.1. Ani s 9 from Anisakis simplex: ABV55106.1. Ani s 8 from Anisakis simplex: BAF75681.1. SXP motif 1 and SXP motif 2 are shown (SXP motif 1 ([I:V]PPFLXGAPXXVV) and SXP motif 2 ([F:L]SP[E:A]A[R:K]XADAX-[M:L][S:T]AIA).

\subsection{Natural Asc 15 in the A. lumbricoides Extract}

Mature Asc 15 was expressed in E. coli origami (DE3) as a hexa-histidine-tagged protein. Under sodium dodecyl sulphate-polyacrylamide gel electrophoresis (SDS-PAGE, reduced conditions), rAsc 1 5 migrated at a molecular mass of $\sim 16 \mathrm{KDa}$ (Figure 2A); this result agreed with theoretical molecular weight of tagged recombinant of $16.9 \mathrm{kDa}$. Approximately 25 milligrams of the recombinant protein were obtained from $1 \mathrm{~L}$ of the expression medium. rAsc 15 was purified to homogeneity, as determined by SDS-PAGE and Coomassie staining. 


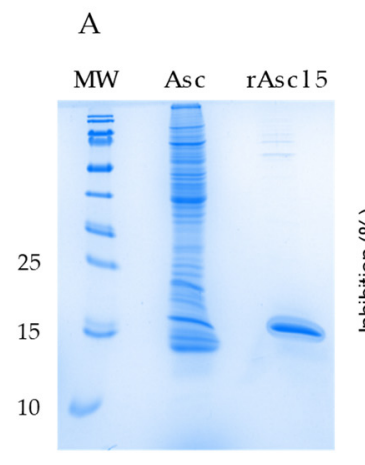

B

C
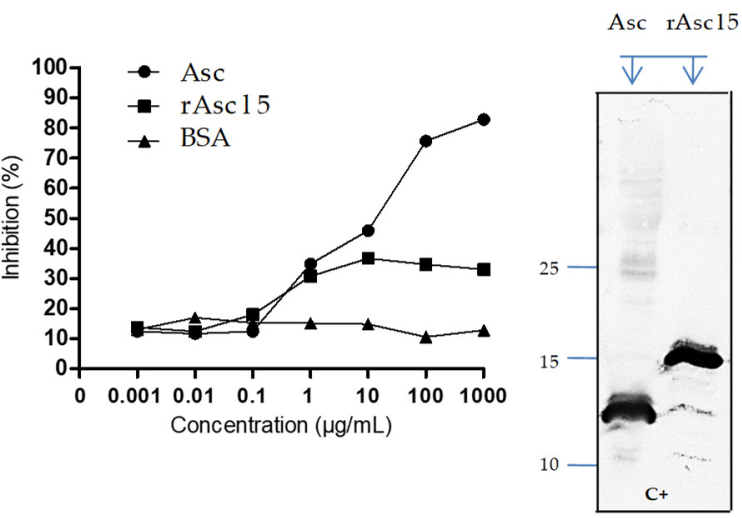

Asc rAscl5

Asc rAsc15
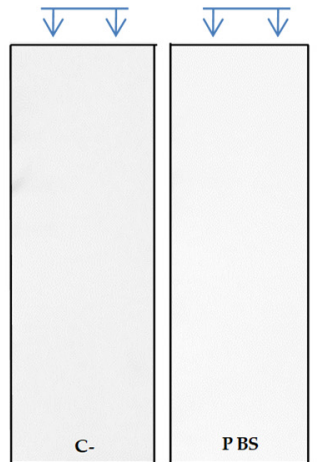

D 1 MKYLITVTCL FVLALVEGQT PSRVPPFLVG APESAVKDFF ELIKKDEEKT DPEIEADIDA FVAKLGADYT NKFIAFKAEL

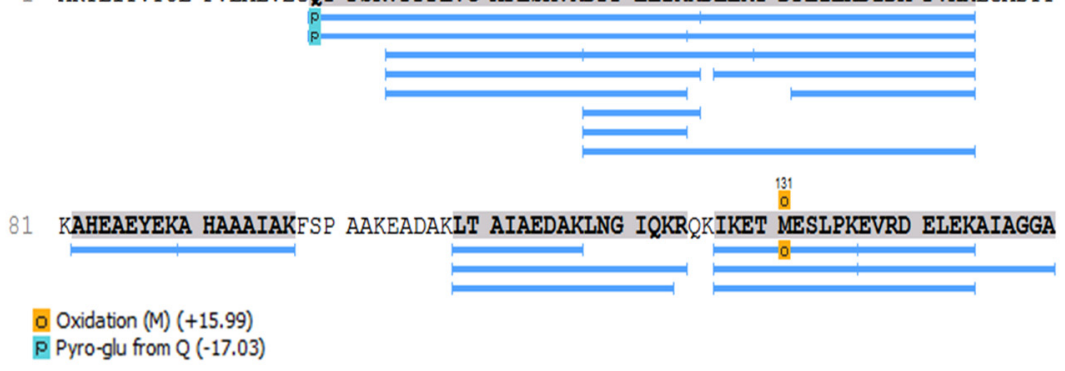

Figure 2. rAsc 15 and its natural counterpart in Ascaris lumbricoides extract. (A) Sodium dodecyl sulphate-polyacrylamide gel electrophoresis (SDS-PAGE) of A. lumbricoides extract ( $5 \mu \mathrm{g}$ ) and rAsc 15 $(1 \mu \mathrm{g})$. (B) Enzyme-linked immunosorbent assay (ELISA) inhibition using a pool of sera with positive IgE to Ascaris; A. lumbricoides extract in solid phase. (C) Western blot probed with sera from mice immunized with rAsc $15+$ Alum $(C+)$ or phosphate-buffered saline (PBS) + Alum (C-) and PBS (as buffer control for non-specific binding of rat AP-conjugated anti-mouse IgG1 antibody) shows that natural Asc 15 (nAsc 15) is recognized in the A. lumbricoides extract (Lane Asc) and rAsc 15 is recognized as well. Asc: A. lumbricoides extract. (D) Mass spectrometric analysis of peptide coverage of nAsc 15. Blue lines indicate peptides identified by tandem mass spectrometry (MS/MS) from the A. lumbricoides extract matching mature sequence of Asc 15. Amino acid sequence of Asc 15 deposited in GenBank under accession number MN275230 is shown. Amino acids from 1 to 18 correspond to the signal peptide, mature sequence of Asc 15 starts in amino acid number 19.

The purified rAsc 15 inhibited around 30\% of the IgE-binding to the A. lumbricoides extract, as determined in enzyme-linked immunosorbent assay (ELISA) inhibition (Figure 2B). Also, sera pool from Ascaris-positive IgE individuals recognized rAsc 15 by WB (Figure S1). As expected, sera pool from infected subjects detected several bands in the A. lumbricoides extract, including a band close to $\sim 14$ KDa.

In order to have an accurate identification of natural Asc 15 and to further evaluate its identity with the recombinant allergen, we used sera from mice immunized with rAsc 15 to identify the natural protein (nAsc 15) in the extract (Figure 2C, lane for Asc). In the WB, mice polyclonal sera recognized one band with a molecular weight of $\sim 14 \mathrm{kDa}$ in the A. lumbricoides extract (Figure 2C), in agreement with the theoretical molecular weight of the mature nAsc 15 . The amino acid sequence of nAsc 15 was confirmed by mass spectrometry performed using the in-solution trypsin-digested A. lumbricoides extract (Figure 2D and Table S2). High coverage (77\%) of the protein sequence was obtained. In Figure 2D the amino acid sequence of nAsc 15 is shown. The blue lines indicate the peptides identified by tandem mass spectrometry (MS/MS) sequencing. 


\section{3. rAsc 15 Is a Monomeric Protein}

rAsc 15 was analyzed according to mass distribution of the protein in solution in DLS experiments showing that it has only one peak at $17.41 \mathrm{kDa}$ in close agreement with the theoretical mass value of the hexa-histidine-tagged recombinant $(16.9 \mathrm{kDa})$ and revealed a hydrodynamic radius $(\mathrm{Rh})$ of around $2.02 \mathrm{~nm}$. This indicates that rAsc 15 is a monomer (Figure 3A). rAsc 15 does not form aggregates, a feature also described for Ani s 5 [14]. High concordance was found between theoretical and experimental amino acid composition of rAsc 15 , confirming the identity of the recombinant and its concentration $(950 \mu \mathrm{g} / \mathrm{mL})$. The content of alpha helical structures was determined by Fourier transform infrared (FTIR) spectroscopy, being $52.8 \%$.

A

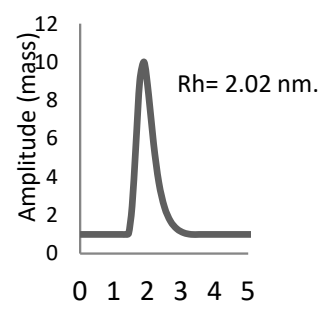

B
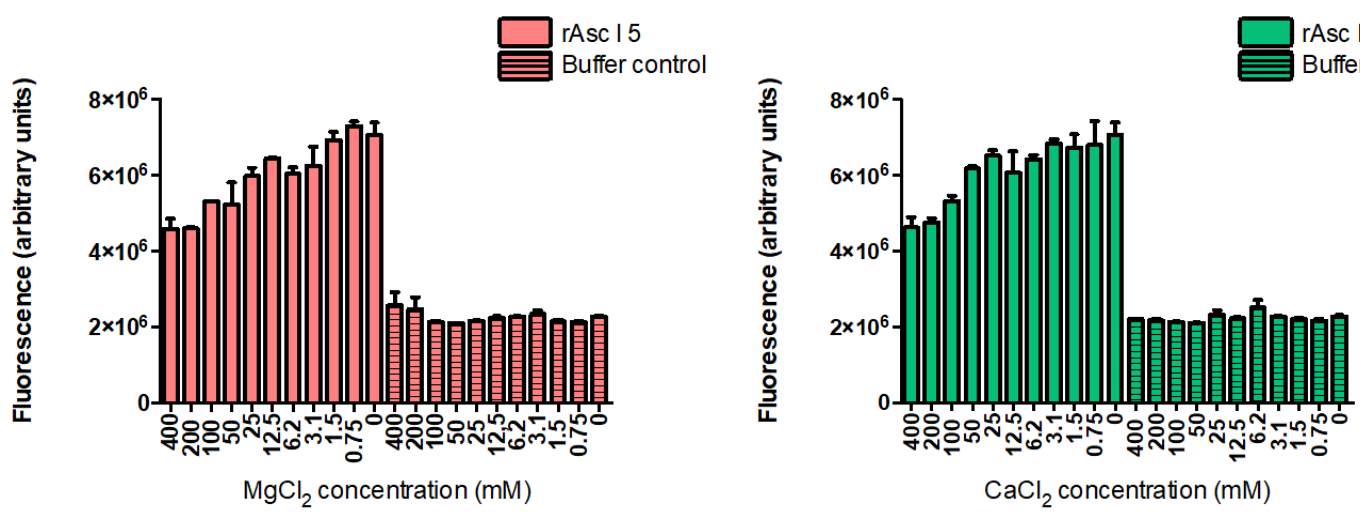

C
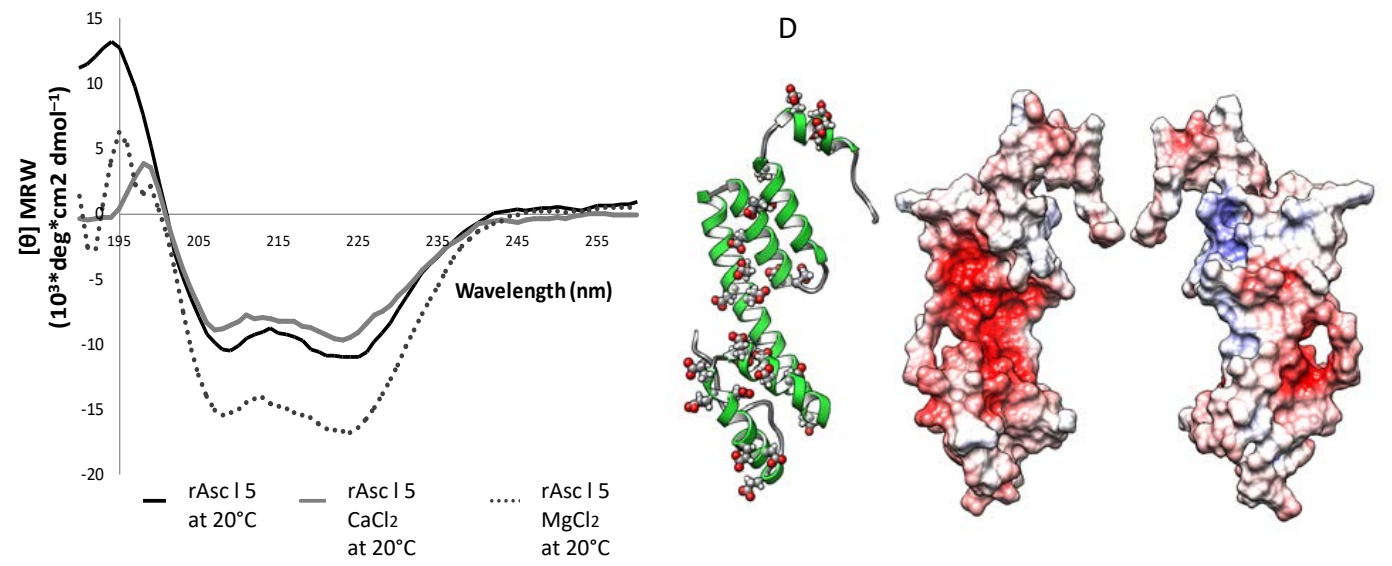

Figure 3. Physicochemical properties of recombinant Asc 15. (A) Hydrodynamic radius (Rh) determined by dynamic light scattering (DLS). (B) 8-anilino-1-naphthalenesulfonic acid (ANS) assay, concentration dependent reduction of ANS binding to rAsc 15 preincubated with different concentrations of $\mathrm{Ca}^{2+}$ or $\mathrm{Mg}^{2+}$. (C) Circular dichroism spectra of rAsc 15 alone $(100 \mu \mathrm{g} / \mathrm{mL})$ or in presence of $\mathrm{CaCl}_{2}(74 \mathrm{mM}$ $\mathrm{CaCl}_{2}$ ) or $\mathrm{MgCl}_{2}(221 \mathrm{mM})$ measured at $20^{\circ} \mathrm{C}$. (D) Homology model of Asc 15 based on Ani s 5 structure (2MAR_A). Left side shows a ribbon representation of Asc 15 . Center and right side show electrostatic surface of Asc 15. Negative charges are in red, positive charges are in blue. Right side, $180 \mathrm{u}$ rotated view. 


\subsection{Calcium and Magnesium Induce Structural Changes in rAsc 15}

Given the sequence similarity between Ani s 5 and Asc 15, we explored if rAsc 15 was able to bind $\mathrm{Ca}^{2+}$ or $\mathrm{Mg}^{2+}$. Garcia-Mayoral et al. [14], showed that the Ani s 5 structure resembles a Calmodulin-like fold. During Ani s 5's physicochemical characterization, its ability to bind $\mathrm{Ca}^{2+}$ and $\mathrm{Mg}^{2+}$ was evaluated [14]. Also, we investigated if these ligands induced structural changes in Asc 15 , as has been described for Calmodulin, where remarkably changes in individual domains are observed after $\mathrm{Ca}^{2+}$ binding [15]. As a first approach, we studied rAsc 15 by ANS experiments. ANS is a probe that increases its fluorescence upon binding to proteins (ANS alone has low fluorescence properties). ANS also has been used to correlate changes in fluorescence intensity with changes in protein tertiary structure [16]. If a natural ligand binds to the protein, less contact surface could be available for ANS binding and an expected dose-dependent reduction of the signal can be observed, closely related with changes in protein structure. As shown in Figure 3B, there were changes in ANS fluorescence when $\mathrm{Ca}^{2+}$ or $\mathrm{Mg}^{2+}$ were added to the protein preparation, detected as a dose-dependent decrease of the fluorescence signal, which is concordant with changes in protein structure and displacement of ANS by metal ions, suggesting that rAsc 15 binds both $\mathrm{Ca}^{2+}$ and $\mathrm{Mg}^{2+}$. To further evaluate possible structural changes in rAsc 15 induced by $\mathrm{Ca}^{2+}$ or $\mathrm{Mg}^{2+}$ we performed circular dichroism (CD) spectroscopy experiments. CD spectra confirmed that there were changes in rAsc 15's secondary structural elements induced by the addition of $\mathrm{Ca}^{2+}$ or $\mathrm{Mg}^{2+}$ (Figure 3C). Protein preparations used in CD assay were run in SDS-PAGE gel, as shown in Figure S2. Structural changes in rAsc 15 are consistently demonstrated by $\mathrm{CD}$ and ANS fluorescence data, and might be necessary for interaction between Asc 15 and calcium/magnesium.

\subsection{Three-Dimensional Structure Model of Asc 15 Comprises Six Alpha Helices with Negatively Charged Patches and Predicted Calcium and Magnesium-Binding Sites}

The 3D structure model of Asc 15 comprises six alpha helices as shown in ribbon representation of Figure 3D (left side). Electrostatic surface representations of Asc 15 are also shown (center and right side). Negative and positive charges, as well as hydrophobic patches, are represented in the structure. Negative patches occupy most of a cavity depicted on the surface of Asc 15 (red color) and come from aspartic (Asp) and glutamic (Glu) acid highlighted in red in the sequence of Asc 15 showed in Figure S3A, where they represent $19.7 \%$ of total amino acids content in the mature sequence. Carboxyl groups of Asp and Glu are able to coordinate to $\mathrm{Ca}^{2+}$ [17]. The major coordinating ligands for magnesium as other alkaline-earth metals are carboxyl groups from Asp/Glu, additionally phosphate groups from the nucleic acid backbone and imidazole ring from histidine side chains [18]. In the Asc 1 5 model, three binding sites were predicted for $\mathrm{Ca}^{2+}$ and one for $\mathrm{Mg}^{2+}$, involving residues such as Asp, Glu, His and Lys (Figure S3B). Some of the Asp/Glu predicted in Asc 15 (Figure S3A) as metal binding residues are conserved in aligned sequences in Figure 1, especially Asp from SXP motif 2 (88D) (Figure S3A). Interestingly, this residue was predicted to be involved in $\mathrm{Mg}^{2+} \mathrm{binding}$. Another annotation about the predicted $\mathrm{Mg}^{2+}$ binding site is that it is close to one of the $\mathrm{Ca}^{2+}$ binding sites where the Glu residue (70E) interacts with both ions (Figure S3B,C). In the Figure S3C, three Ca ${ }^{2+}$ and one $\mathrm{Mg}^{2+}$ ions have been added to the Asc 15 model (the model has been rotated to appreciate residues involved in ion binding). The structure was energy minimized in the presence of all four ions in chimera. In the Figure $\mathrm{S} 3 \mathrm{C}, \mathrm{Ca}^{2+}$ ions are shown in blue, the $\mathrm{Mg}^{2+}$ ion is shown in magenta.

\section{6. rAsc 15 Binds IgE, Activates Basophils and Induces Histamine Release}

We investigated the frequency of IgE sensitization to rAsc 15 in 254 children from the "Risk Factors for Asthma and Allergy in the Tropics" (FRAAT) cohort and 298 all-age subjects from Santa Catalina (SC). The frequency of IgE-binding to rAsc 15 in the FRAAT cohort and SC were 31.9\% and 52.0\% respectively. Sensitization to $\mathrm{rAsc} 15$ was higher in individuals also sensitized to the Ascaris extract (FRAAT: $44 \%$ vs. $23 \%, p<0.001$; SC: $58 \%$ vs. $47 \%, p=0.05$, Figure 4 A). Frequencies of IgE reactivity 
to rAsc 15 were also analyzed between asthmatic patients and controls from SC (Table 1), finding no significant difference $(58.0 \%$ vs. $50.8 \%, p=0.35)$.

A

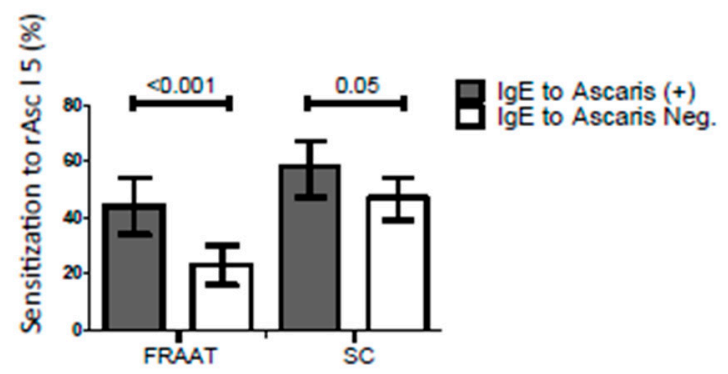

B
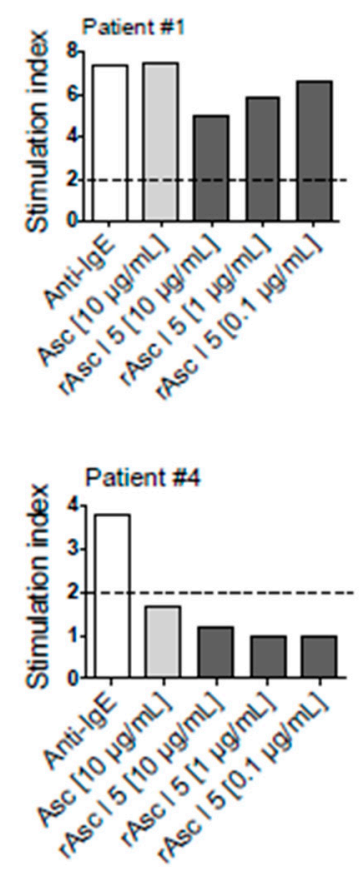

C

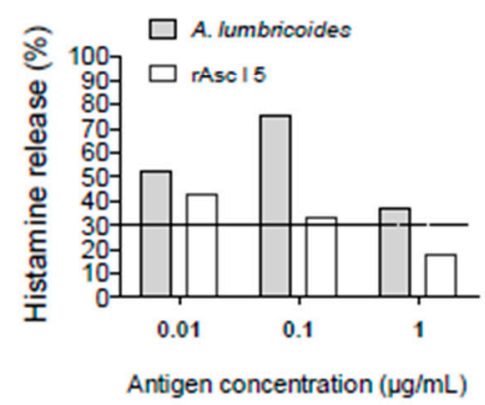

Patient \#1

Antigen concentration $(\mu \mathrm{g} / \mathrm{mL})$
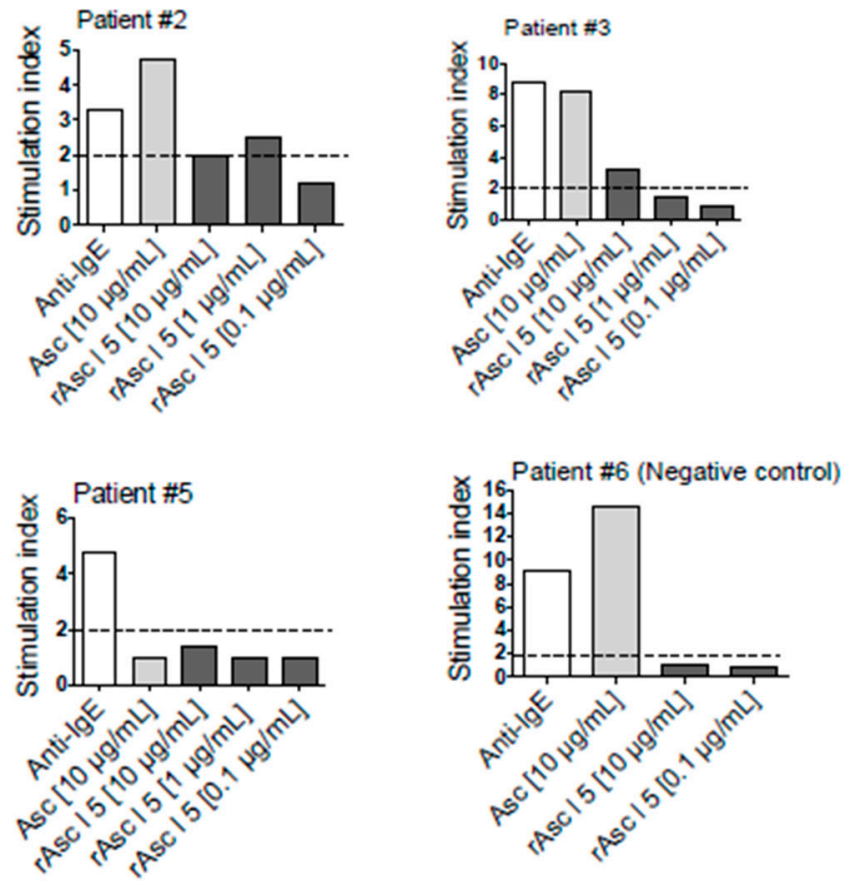

Patient \#6 (Negative control)

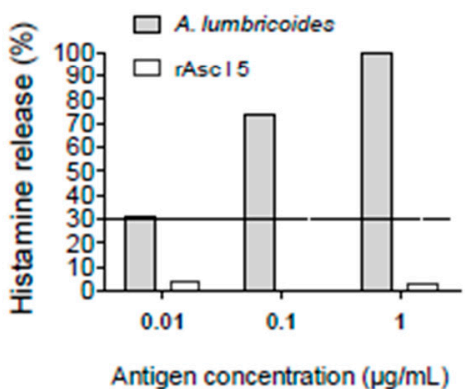

Figure 4. Allergenic properties of rAsc 15 as evaluated in humans. (A) Bar graphs summarizing frequencies of sensitization to rAsc 15 between individuals sensitized and non-sensitized to Ascaris: 254 children from the FRAAT cohort and 298 all-age subjects from Santa Catalina (SC). Error bars indicate 95\% confidence intervals. Cut off for IgE sensitization to rAsc 15 was 0.145 and cut off for $\operatorname{IgE}$ sensitization to Ascaris was $0.35 \mathrm{kU}$ / $/$. (B) Stimulation index of CD203c based-basophil activation test, including samples stimulated with anti-IgE, Ascaris lumbricoides extract $(10 \mu \mathrm{g} / \mathrm{mL})$ and rAsc 15 (10, 1 or $0.1 \mu \mathrm{g} / \mathrm{mL}$ ) from five Asc 15 -sensitized patients and one Asc 15 non-sensitized negative control. (C) Percentage of histamine release determined by ELISA in a selected Asc 15 -sensitized patient and the negative control. 
Table 1. Serological and parasitological variables, Santa Catalina (SC).

\begin{tabular}{cccc}
\hline Variables & Asthmatics, $\boldsymbol{n}$ (\%) & Non Asthmatics, $\boldsymbol{n}$ (\%) & $p$ Value \\
\hline & $n=50$ & $n=248$ & \\
Asc 15 sensitization $^{1}$ & $29(58.0 \%)$ & $126(50.8 \%)$ & 0.353 \\
IgE to Asc 15, OD ${ }^{2}$ & $0.154(0.114-0.253)$ & $0.146(0.115-0.233)$ & 0.388 \\
Ascaris spp. sensitization & $26(50 \%)$ & $104(42 \%)$ & 0.190 \\
IgE to Ascaris spp ${ }^{2}$ & $0.444(0.036-1.475)$ & $0.251(0.07-1.134)$ & 0.821 \\
A. lumbricoides by stool $^{\text {examination }}{ }^{1}$ & $\boldsymbol{n}=\mathbf{4 8}$ & $\boldsymbol{n}=\mathbf{2 4 2}$ & \\
A. lumbricoides epg $^{2}$ & $27(56.3 \%)$ & $168(69.4 \%)$ & 0.076 \\
${\text { Positive SPT to } \text { Ascaris }^{1}}^{1}$ & $546(0-2047)$ & $689(0-2340)$ & 0.197 \\
\hline
\end{tabular}

1 Determined as positive or negative $\mathrm{n}(\%) . p$ values by Pearson chi-square test. Cut off for rAsc 15 sensitization was 0.145. Cut off for Ascaris spp. sensitization was $0.35 \mathrm{kU} / \mathrm{l}$. Skin prick test (SPT) was considered positive if the mean diameter of the wheal at $15 \mathrm{~min}$ was $>3 \mathrm{~mm}$ than the negative control. ${ }^{2}$ Medians (interquartile range, 25th-75th). $p$ values were calculated using the Mann-Whitney U-test. OD: Optical density units. epg: Eggs per gram of faeces.

The immunological characteristics of samples used in CD203 based BAT and histamine release are described in Table 2. Basophil activation results of individual samples are shown in Figure 4B as the stimulation index (SI). rAsc 15 induced significant upregulation of basophil CD203c expression in 3 out of 5 Asc 15 -sensitized patients (SI range from 2.0 to 6.6). The highest basophil activation value was observed in patient 1 (SI 6.6), like that obtained with A. lumbricoides extract (SI 7.5). No activation was observed in the cells from a rAsc 15 non-sensitized control (patient \#6, as negative control). $A$. lumbricoides extract induced basophil activation in all Ascaris-sensitized patients (patients \#1, \#2 and \#3). As expected, anti-human IgE antibodies induced basophil activation that was used as the positive control of the experiment. Histamine release results from a selected patient (patient \#1) and the control (patient \#6) are shown in Figure 4C. The highest percentage of histamine release in the patient 1 stimulated with rAsc 15 reached $42.3 \%$ while there was no histamine release from the control.

Table 2. Immunological characteristics of samples used in basophil activation test and histamine release.

\begin{tabular}{|c|c|c|c|c|c|c|}
\hline \multicolumn{7}{|c|}{ Patients } \\
\hline Data & $\# 1$ & \#2 & $\# 3$ & $\# 4$ & $\# 5$ & \#6 \\
\hline Code & ST371 & ST581 & ASC217 & ST383 & ST438 & $\mathrm{ASC}^{2} 40^{+}$ \\
\hline Diagnosis & Asthma & Parasited & Asthma & Rhinitis & Asthma & Asthma \\
\hline $\operatorname{IgE}$ to $\mathrm{rAsc} 15^{1}$ & 0.29 & 0.51 & 0.29 & 0.38 & 1.20 & 0.12 \\
\hline IgE to Ascaris $^{2}$ & 16.2 & 8.19 & 3.64 & 0.30 & 0.03 & 9.02 \\
\hline IgE to Blomia ${ }^{2}$ & 22.80 & 0.67 & 0.48 & 2.01 & 0.10 & 1.33 \\
\hline IgE to Dp. ${ }^{2}$ & 2.20 & 0.10 & 0.31 & 7.04 & 0.02 & 1.16 \\
\hline Total $\operatorname{IgE}^{2}$ & 642.6 & 727.1 & 588.3 & 478.7 & 228.5 & 975.8 \\
\hline Gender & F & F & $\mathrm{M}$ & F & F & $\mathrm{F}$ \\
\hline Age & 50 & 61 & 35 & 36 & 3 & 28 \\
\hline \multicolumn{7}{|c|}{ Stimulation index (SI) of CD203 based-basophil activation test } \\
\hline Anti-IgE & 7.4 & 3.3 & 8.7 & 3.8 & 4.8 & 9.0 \\
\hline $\mathrm{rAsc} 1510 \mu \mathrm{g} / \mathrm{mL}$ & 5.0 & 2.0 & 3.2 & 1.2 & 1.4 & 1.0 \\
\hline $\mathrm{rAsc} 151 \mu \mathrm{g} / \mathrm{mL}$ & 5.9 & 2.5 & 1.4 & 1.0 & 1.0 & nd \\
\hline rAsc $150.1 \mu \mathrm{g} / \mathrm{mL}$ & 6.6 & 1.2 & 0.9 & 1.0 & 1.0 & 0.9 \\
\hline Ascaris $10 \mu \mathrm{g} / \mathrm{mL}$ & 7.5 & 4.7 & 8.1 & 1.7 & 1.0 & 14.6 \\
\hline \multicolumn{7}{|c|}{ Percentage of histamine release (\%) } \\
\hline Ascaris $0.01 \mu \mathrm{g} / \mathrm{mL}$ & 52.2 & nd & nd & nd & nd & 31.0 \\
\hline Ascaris $0.1 \mu \mathrm{g} / \mathrm{mL}$ & 75.2 & nd & nd & nd & nd & 73.0 \\
\hline Ascaris $1 \mu \mathrm{g} / \mathrm{mL}$ & 37.0 & nd & nd & nd & nd & 100 \\
\hline $\mathrm{rAsc} 150.01 \mu \mathrm{g} / \mathrm{mL}$ & 42.3 & nd & nd & nd & nd & 4 \\
\hline $\mathrm{rAsc} 150.1 \mu \mathrm{g} / \mathrm{mL}$ & 33.2 & nd & nd & nd & nd & 0.4 \\
\hline $\mathrm{rAsc} 151 \mu \mathrm{g} / \mathrm{mL}$ & 18.0 & nd & nd & nd & nd & 3 \\
\hline
\end{tabular}

1 OD: Optical density units. As determined by ELISA. ${ }^{2} \mathrm{kU} / \mathrm{l}$ as determined by ImmunoCAP. Dp: Dermatophagoides pteronyssinus. ${ }^{\dagger}$ rAsc 15 non-sensitized control. nd. Not done. 
2.7. rAsc 15 Induces Specific IgE Production in Immunized Mice and A Positive Passive Cutaneous Anaphylaxis (PCA) Reaction

The immunization protocol to obtain antisera and PCA model is shown in Figure 5A,B. Ova was used as a positive control and induced the strongest IgE responses and extravasated Evans blue levels, followed by Ascaris tropomyosin (Asc 13) and rAsc 15 . However, there were no significant differences among the three responses (Figure 5C,D).

A Immunization schedule: Obtaining antisera

\begin{tabular}{lccc|}
\hline & & & \\
0 day & 7 day & 14 day & 21 day \\
$20 \mu \mathrm{g}$ antigen & $20 \mu \mathrm{g}$ antigen & $20 \mu \mathrm{g}$ antigen & Euthanasia and \\
Alum $2 \mathrm{mg}$ IP & Alum $2 \mathrm{mg}$ IP & Alum 2 mg IP & exsanguination
\end{tabular}

B

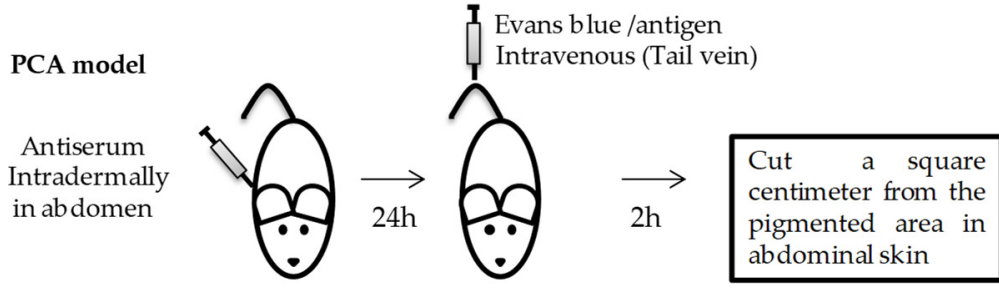

C

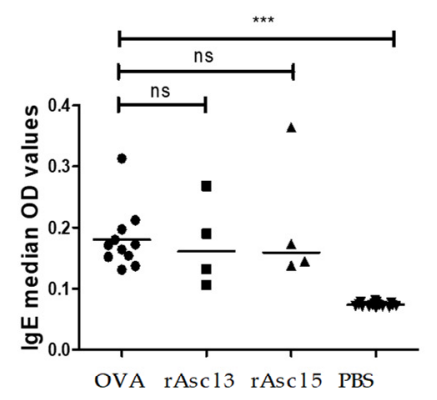

$\mathrm{D}$

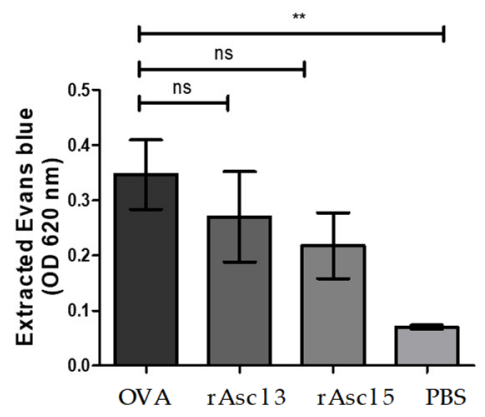

$\mathrm{E}$

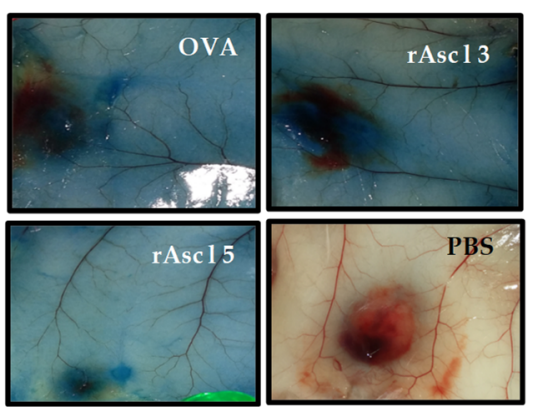

Figure 5. Allergenic properties of $\mathrm{rAsc} 15$ evaluated in a sensitization and passive cutaneous anaphylaxis (PCA) model (A) Immunization schedule of female BALB/c mice using Ascaris molecules plus Alum: Asc 13 and rAsc 15. Positive control OVA. Negative control PBS. IP: intraperitoneal. (B) PCA model in BALB/c mice. (C) Strength of the IgE reactivity to OVA, Asc 13 and rAsc 15, median values are shown. (D) Extracted Evans blue after PCA reaction detected to $620 \mathrm{~nm}$ showed as mean \pm standard error of the mean (SEM) of OD values (OD: Optical density units). Comparison between groups was done by one-way analysis of variance (ANOVA) and Dunnett's multiple comparison test: ${ }^{* *} p<0.05$, *** $p<0.001$, no significance for $\mathrm{p}>0.05$. ns: not significant). (E) Representative pictures after PCA reaction from the pigmented area in abdominal skin.

Representative images of PCA reactions show that extravasated Evans Blue is more intense in OVA, Asc 13 and Asc 15 groups compared with PBS control group (Figure 5E). These results show that 
rAsc 15 can induce specific IgE production and after subsequent rAsc 15 administration, it induces a type I hypersensitivity reaction.

\section{Discussion}

Research on the relationships between helminthiases and allergic responses is important, not only for getting better knowledge of the pathogenesis of both conditions, but also because in places where they are prevalent, clinical repercussions in the diagnosis and management of asthma and other allergic diseases are expected [19]. Also, allergic reactions could jeopardize the safety of potential helminth vaccines. The analysis of the allergenic composition of $A$. lumbricoides is important for evaluating the role of its allergens on the natural history of asthma and other allergic diseases [9], as well as defining an array of species-specific and cross-reactive molecules for component-resolved diagnosis of allergy [20-22].

In a previous study we found that Ascaris extract had at least 12 IgE-binding components [6], since only three allergens have been described, the complete allergenic composition of this nematode remains to be defined. To identify new allergens, we constructed an A. lumbricoides cDNA library and, by using IgE antibodies from Ascaris-sensitized subjects, Asc 15 was discovered. In this study we focused firstly on the physicochemical characterization of Asc 15, with emphasis on structure and ligand binding characteristics, and secondly, we investigated the frequency of IgE recognition of Asc 1 5 and its allergenic activity in humans and in a mouse model of passive cutaneous anaphylaxis.

Asc 15 is a member of the SXP/RAL-2 protein family, which includes proteins from various nematode species and has amino acid sequence similarity with those of nematode origin only, which suggest that Asc 15 could be useful for serological diagnosis purposes. However, additional studies are needed to define this aspect. In SXP/RAL-2 protein family some member have being studied as potential vaccine candidates [23-25] and others are markers of infection [26,27]. Interestingly, there are 3 allergens of Anisakis simplex that belong to this family [28-30]. DUF148 domain (Pfam code PF02520) is present in these proteins and comprises two conserved motifs: SXP1 and SXP2 [26], which are present in Asc 15 (Figure 1). The function of this domain is unknown, but key information comes from Ani s 5, the only member of the SXP/RAL-2 family with 3D structure resolved by NMR composed of six alpha helices with a Calmodulin like fold, with functional studies indicating that Ani s 5 binds with magnesium [14]. Sequence analysis of Asc 15 and its close homologue Ani s 5 indicated that common structural characteristics might be shared. Asc 15 has one predicted binding site for magnesium and two for calcium, and our experimental results have shown that structural changes in Asc 15 are induced by these two metal ions.

Studying the physicochemical properties of allergens helps to understand their biological function and allergenic activities. In addition, it gives the possibility to molecular modifications for experimental or clinical uses. Ani s 5, Ani s 8 and Ani s 9 from Anisakis simplex and now Asc 15 from A. lumbricoides are the only allergens that have been identified in the SXP/RAL-2 protein family. The fold of Ani s 5 is remindful of Calmodulin structure which is the primary calcium binding protein in eukaryotic cells. Calmodulin binds $\mathrm{Ca}^{2+}$ through a helix-loop-helix structure (EF-hand motif), with highly hydrophobic helices and negative residues [31]. Calmodulin function and structure are influenced by calcium concentration. Folding of its individual domains change significantly in response to $\mathrm{Ca}^{2+}$ [15]. Without $\mathrm{Ca}^{2+}$, Calmodulin has a "closed" configuration and after $\mathrm{Ca}^{2+}$ binding it changes to a dumbbell-shaped "open" configuration, in this motion process becomes exposed to non-polar residues such as methionine that interact with Calmodulin target proteins. These targets are hundreds of intracellular proteins involved in a wide array of functions [32,33].

As described for Ani s 5, our results show that Asc 15 is a monomeric protein. Some proteins require calcium or magnesium ions to be functional. The binding site is a region in the protein where metal ions will bind as a result of electrostatic interactions with residues of opposite charge through coordination bonds [17]. The 3D structure model of Asc 15 has negatively charged patches rich in Glu and Asp that provide opposite charge to divalent cations such as typical alkaline-earth metal, $\mathrm{Ca}^{2+}$ and 
$\mathrm{Mg}^{2+}$. Highly negative proteins are usually involved in binding to $\mathrm{Ca}^{2+}$ and $\mathrm{Mg}^{2+}$ [17]. Calcium ions can stabilize the secondary and tertiary structures of proteins that, for example allow binding of other ions [34]. Calcium coordination bond distance is around 2.4-2.5 $\AA$, while for magnesium it is typically $2.08 \AA$. This agrees with our in in silico analysis where we used a bond distance within the range of 3.5 A. Our bioinformatics analysis support CD and ANS-experimental results that demonstrated structural changes in rAsc 15 after adding $\mathrm{Ca}^{2+}$ or $\mathrm{Mg}^{2+}$, which could be a consequence of its metal binding behavior whereby both ions may act as regulators that reposition/modify folding of secondary structural elements in Asc 15.

The implications of these observations will serve as a base for future studies and to further analyze and get experimental structural data on the atomic level by X-ray crystallography or NMR spectroscopy and confirm residues involved in metal binding and its stoichiometry, as well as, to study possible effects of one metal ligand on the binding of the other. In addition, since protein ligands can influence allergenicity by affecting allergen tertiary structure and biochemical attributes [35-37] the study of structural modifications induced by ligands might help to analyze possible relationships between allergen structure and allergenicity.

rAsc 15 binds IgE with high frequency in Ascaris-sensitized individuals as evaluated in different populations: $44 \%$ in FRAAT and $58 \%$ in SC. In the SC population, it was possible to evaluate the clinical impact of this sensitization, showing that there is no difference in the degree or frequency of sensitization between asthmatic and non-asthmatic individuals (Table 1). Although the number of cases is small and this is not a main objective of this work, our data suggest that contrary to Ascaris tropomyosin, Asc 15 does not have a significant impact on asthma evolution. However, more studies should be undertaken to address this point, not only in asthma [20] but also to explore the effect of Asc 1 5 sensitization on other allergic diseases such as atopic dermatitis, an aspect of ascariasis that have been little investigated [38]. The strength of the IgE response to $\mathrm{rAsc} 15$ is similar to that observed in other studies against Ascaris tropomyosin or ABA-1 [9,20,39], and greater than that detected for glutathione transferase allergen (Asc 113) [8,20]. In both in vitro and in vivo tests for allergenic activity, rAsc 15 induces positive basophil activation and histamine release in humans. Also, rAsc 15 induces specific IgE production and positive PCA reaction with similar strength as that of tropomyosin. All these results from humans and mice suggest that specific IgE to $\mathrm{rAsc} 15$ can induce allergic inflammation.

ELISA inhibition experiments showed that rAsc 15 inhibits around $30 \%$ of $\operatorname{IgE}$ binding capacity of the patient sera directed against $A$. lumbricoides extract, indicating that the response to Asc 15 may be a third part of the total extract reactivity, supporting the potential usefulness of Asc 15 in arrays for component resolved diagnosis of Ascaris allergy.

In the SXP/RAL-2 protein family there are some antigens that have been proposed as potential vaccine candidates for Ascaris-infection prevention with results supported in mouse and pig experimental models, such as As14 [23] and As16 [24,40,41]. Our findings about the allergenic activity of Asc 15 might have implications for the use of Ascaris molecules as potential vaccines against ascariasis and in a general way in the use of vaccines to prevent helminthiases. Considering the allergenic activity of Asc 15, it is reasonable to think that it could be useful to evaluate the allergenic properties of nematode-candidate antigens before designing vaccines from the SXP/RAL-2 family. To our knowledge, safety of nematode vaccines has been studied only in one phase I trial of a vaccine candidate from Necator americanus in which the vaccination of healthy adults living in a hookworm-endemic area of Brazil with a single dose of Na-ASP-2 antigen (Ancylostoma-secreted protein 2) resulted in generalized urticarial reactions in several volunteers [42]. In this study, the authors suggest that in endemic areas nematode infections might induce $\operatorname{IgE}$ responses to candidate vaccine antigens and hypersensitivity reactions, highlighting the importance of performing serological studies before the administration of vaccine candidates for preventing helminth infections [42].

In summary, we described the identification and physicochemical characterization of Asc 15 a new allergen from A. lumbricoides. This work contributes to the knowledge of physicochemical properties of SXP/RAL-2 family members and to the growing list of Ascaris lumbricoides allergens. Asc 15 might be 
useful for diagnosing of A. lumbricoides infection and for component-resolved diagnosis of allergy. Asc 15 is the second member of SXP/RAL-2 protein family that has been physicochemically characterized. The study of biological functions of Asc 15 and other members of the SXP/RAL-2 protein family may be useful to reveal the role of these molecules in nematodes' metabolism and host-parasite relationships. Analyzing the possible links between infection and host responses (such as IgE and Th2 immunity) may contribute to understanding the relationship between helminth infections and allergy.

\section{Materials and Methods}

\subsection{Subjects}

The participants were from two well-characterized populations $[39,43]$, here summarized as follows: (1) A population from Santa Catalina (SC, $\mathrm{n}=298$, aged 1 to 88 years), a small tropical farming/fishing town located at the North of Colombia [39] where current ascariasis was determined by stool analysis with a prevalence of infection of $62.5 \%$ [39]. Individuals with available serum samples were included in this study. Using an "International Study of Asthma and Allergies in Childhood" (ISAAC)-based questionnaire previously validated in our country, a 'case' of asthma was defined as described previously [44]. Affirmative cases were confirmed by medical evaluation, 50 were asthmatic patients and 248 non-asthmatic controls, recruited from the same neighborhoods [39]; (2) The second population were children of four-year-old (range: $47-57$ months) from the FRAAT cohort $(n=254)$. This is a community-based birth cohort for a prospective follow-up and collection of epidemiological data and biological samples $[12,21,43]$.

\subsection{Ethical Statement}

This study was conducted following the ethical principles for medical research stated in the Declaration of Helsinki. The Bioethics Committee of the University of Cartagena approved the study (Minute 17-05-2012). A full verbal explanation of the investigation was given to each participant and written informed consent was obtained from all subjects or their parents or legal guardians.

\subsection{IgE Immunoscreening of A. lumbricoides cDNA Library}

Total RNA extraction was performed from three A. lumbricoides adult females using TRIzol (Gibco, Invitrogen, Carsbald CA, USA). Messenger RNA was purified by a batch method (Oligotex, Qiagen $\mathrm{GmbH}$, Hilden, Germany), and cDNA synthesis was performed using cDNA Synthesis Kit (Agilent) following the manufacturer's instructions. The cDNA inserts were ligated into the Uni-ZAP XR vector (Agilent) and packaged into bacteriophage Gigapack III Gold (Agilent). Infection of host bacteria was performed in Escherichia coli XL1-Blue MRF'. The cDNA library was stored at $-80^{\circ} \mathrm{C}$ until use [45]. IgE immunoscreening was done using five sera from $A$. lumbricoides-infected children with positive IgE to Ascaris ( 9.81 to $28.6 \mathrm{kU} / \mathrm{A}$ ), and five negative controls ( $\mathrm{IgE}$ lower than $0.08 \mathrm{kU}_{\mathrm{A}} / \mathrm{L}$ ). Infection of host bacteria with the phages was undertaken at a density of 5000 plaque-forming units per Petri dish (150 mm diameter). Plaques were transferred to nitrocellulose filters (Amersham Corp., Arlington Heights, IL, USA) soaked in isopropyl $\beta$-D-1-thiogalactopyranoside (IPTG). The filters were blocked for $1 \mathrm{~h}$ with $5 \%$ solution of skim milk powder and were washed three times with PBS containing $0.1 \%$ Tween 20. They were incubated overnight at room temperature, with the pool of human sera. IgE binding was detected by incubating the membranes with an alkaline phosphatase-conjugated anti-human IgE antibody-(Sigma) diluted 1:500 in PBS containing $0.2 \%$ bovine serum albumin (BSA) and $0.05 \%$ Tween-20, and developed with 5-bromo-4-chloro-3-indolyl-phosphate/nitro blue tetrazolium (BCIP/NBT) substrate (BIO-RAD) dissolved in alkaline phosphatase buffer (pH 9.5).

\subsection{Isolation, Sequencing, and Nucleotide Analysis of IgE-Binding Clones}

Agar lysis plaques were obtained and placed in $1.5 \mathrm{~mL}$ microfuge tubes with $100 \mu \mathrm{L}$ of SM buffer and stored at $4{ }^{\circ} \mathrm{C}$. For each of the positive clones the screening was repeated to obtain isolated plaques. 
The DNA inserts were amplified directly by polymerase chain reaction (PCR) with the universal primers "T7 promoter" and "M13 reverse", selected according to the cloning sites of the phagemid pBluescript SK (-). Conditions for the PCR in a thermocycler S1000 (BIO-RAD) were as follows: initial denaturation of $5 \mathrm{~min}$ at $95^{\circ} \mathrm{C}$, followed by 35 cycles of $1 \mathrm{~min}$ at $94^{\circ} \mathrm{C} ; 45 \mathrm{~s}$ at $52^{\circ} \mathrm{C}, 1 \mathrm{~min}$ at $72{ }^{\circ} \mathrm{C}$ and a final extension at $72{ }^{\circ} \mathrm{C}$ for $5 \mathrm{~min}$. Analysis of the amplification product was performed in a $1 \%$ agarose gel in the presence of SYBR safe DNA gel stain (Invitrogen). Nucleotide sequences were undertaken with the BigDye Terminator v3.1 Cycle Sequencing Kit using capillary electrophoresis and ABI3730x1 sequencer. Online bioinformatics tools including Basic Local Alignment Search Tool (BLASTN) and open reading frame (ORF) finder tool (http://www.ncbi.nlm.nih.gov/gorf/gorf.html) were used to identify the nucleotide sequences and determine similarities with previously reported sequences in GenBank. Clustal Omega (https://www.ebi.ac.uk/Tools/msa/clustalo/) was used to multiple alignments of cDNA and protein sequences and SignalP-5.0 Server (http://www.cbs.dtu.dk/services/SignalP/) to analyze the presence of a signal peptide on the protein sequence.

\subsection{Cloning, Expression, and Purification of Recombinant Asc 15}

The cDNA sequence coding for Asc 15 protein was subcloned without signal peptide into the expression vector pET-45b+ (GenScript, USA) and E. coli Origami (DE3) competent cells were transformed by electroporation. The E. coli cultures were grown overnight in Luria-Bertani medium containing $100 \mathrm{mg} / \mathrm{L}$ ampicillin at $37^{\circ} \mathrm{C}$. Expression of the recombinant protein was induced by adding IPTG to a final concentration of $1 \mathrm{mM}$ at an $\mathrm{OD}_{600}$ of 0.5 . After cultivation for additional $5 \mathrm{~h}$ at $37^{\circ} \mathrm{C}$, E. coli cultures were centrifuged $\left(30 \mathrm{~min}, 3500 \mathrm{rpm}, 4^{\circ} \mathrm{C}\right)$. Induced cultures were re-suspended in native buffer ( $\left.50 \mathrm{mM} \mathrm{NaH}_{2} \mathrm{PO}_{4}, 300 \mathrm{mM} \mathrm{NaCl}\right)$, incubated with lysozyme $(1 \mathrm{mg} / \mathrm{mL}, 30 \mathrm{~min}$ on ice) and sonicated. Lysates were incubated with Nickel-Nitrilotriacetic Acid (Ni-NTA) resin (Invitrogen) for one hour, washed with native buffer plus $20 \mathrm{mM}$ imidazole, and eluted with native buffer plus $250 \mathrm{mM}$ imidazole as a $6 \mathrm{xHis}$-tagged protein [8]. The purified recombinant was directly subjected to SDS-PAGE analysis.

\subsection{A. lumbricoides Extract Preparation, Enzyme-Linked Immunosorbent Assay (ELISA) Inhibition and Western Blot (WB)}

Adult $A$. lumbricoides worms were washed in sterile saline solution $(0.9 \% \mathrm{p} / \mathrm{v}$ of sodium chloride) with penicillin and streptomycin, then washed with PBS and cut in small pieces that were frozen with liquid nitrogen and homogenized using mortar and pestle. After the liquid nitrogen was evaporated completely, macerated worms were diluted in PBS in a 1:10 proportion (1g of worms in $10 \mathrm{~mL}$ ) and centrifuged. The supernatant (extract) was dialyzed in water using a 3500 Dalton molecular weight cutoff membrane (Spectra/Por $\left.{ }^{\circledR}\right)$. Protein concentration $(1.3 \mathrm{mg} / \mathrm{mL})$ was determined by Bradford (Thermo). The lyophilized extract was kept at $-20{ }^{\circ} \mathrm{C}$ until used. For ELISA inhibition between rAsc 15 and A. lumbricoides extract, a pool of serum samples (1:5 dilution) from Ascaris-sensitized patients (Table S1) was incubated with the inhibitors rAsc 15, A. lumbricoides extract or BSA (Bovine serum albumin) respectively at different concentrations $(0.001,0.01,0.1,1,10,100$ and $1000 \mu \mathrm{g} / \mathrm{mL})$. After adsorption during $10 \mathrm{~h}$ at $4{ }^{\circ} \mathrm{C}, 100 \mu \mathrm{L}$ of the inhibited pool was loaded into each well coated with $A$. lumbricoides extract on solid phase. IgE-binding was measured by ELISA, and the results were expressed in percentage of inhibition, calculated as follows: percent of inhibition $=$ OD without inhibitor-OD with inhibitor/OD without inhibitor X 100. BSA was the nonrelated inhibitor control [6]. WB using sera from Ascaris-sensitized patients was undertaken to evaluate IgE-reactivity of the recombinant Asc 15. The protocol was performed as described before [9]. A pool of sera from 5 Ascaris-sensitized patients with specific IgE to Ascaris spp. ranged from 3.88 to $8.54 \mathrm{kU}_{\mathrm{A}} / \mathrm{L}$ as determined by ImmunoCAP and 5 negative controls with specific $\operatorname{IgE}$ to Ascaris spp. bellow $0.08 \mathrm{kU} / \mathrm{L}$ and PBS buffer control were used to evaluate reactivity of $\mathrm{rAsc} 15$. WB using sera from mice immunized with rAsc 15 (see below) was used to identify its native counterpart (nAsc 15) in the A. lumbricoides extract. For gel electrophoresis, $10 \mu \mathrm{g}$ of A. lumbricoides extract and $0.375 \mu \mathrm{g}$ of $\mathrm{rAsc} 15$ were applied to 
each well of $12 \%$ SDS-PAGE. After SDS-PAGE, proteins were blotted onto a nitrocellulose membrane (Whatman, Maidstone, UK) and incubated with sera pool of $4 \mathrm{rAsc}$ 15-immunized mice diluted 1:200 and bound IgG1 was detected using a rat AP-conjugated anti-mouse IgG1 antibody (1:2000, Southern Biotech) [46].

\subsection{Peptide Analysis by Nano-Liquid Chromatography-Tandem Mass Spectrometry (LC-MS/MS)}

$5 \mu \mathrm{L}$ of A. lumbricoides extract $(1000 \mu \mathrm{g} / \mathrm{mL})$ were digested with the ProteoExtract All-in-One Trypsin Digestion Kit (EMD Millipore, Billerica, MA, USA) and desalted using C18ZipTips (EMD Millipore, Billerica, MA, USA). Resulting peptides were separated by reverse-phase nano-high performance liquid chromatography (HPLC, Dionex Ultimate 3000, Thermo Fisher Scientific, Bremen, Germany, column: PepSwift Monolithic Nano Column, $100 \mu \mathrm{M} \times 25 \mathrm{~cm}$, Dionex). The column was developed with an acetonitrile gradient (Solvent A: $0.1 \%(v / v)$ FA/ $0.01 \%(v / v)$ TFA $/ 5 \%(v / v)$ ACN; solvent B: $0.1 \%$ $(v / v) \mathrm{FA} / 0.01 \%(v / v) \mathrm{TFA} / 90 \%(v / v) \mathrm{ACN} ; 5-45 \% \mathrm{~B}$ in $60 \mathrm{~min})$ at a flow rate of $1 \mu \mathrm{L} / \mathrm{min}$ at $\left.55{ }^{\circ} \mathrm{C}\right)$. The HPLC was directly coupled via nano electrospray to a $Q$ Exactive Orbitrap mass spectrometer (Thermo Fisher Scientific). Capillary voltage was $2 \mathrm{kV}$. For peptide assignment, a top $12 \mathrm{MS} / \mathrm{MS}$ method was used with the normalized fragmentation energy set to $27 \%$. Proteins were identified with PEAKS Studio 8 (Bioinformatics Solutions, Waterloo, Canada), using the UniProt (SwissProt/TrEMBL) sequence database. For the identification of post-translational modifications and amino acid exchanges, the PTM and Spider modules of PEAKS Studio were used. Only peptides with high confidence scores $(-10 \lg p \geq$ 35 , corresponding to false discovery rate $(\mathrm{FDR})<0.5 \%$ ) were considered in the database searches.

\subsection{Size Exclusion Chromatography, Amino Acid Composition, Aggregation Behavior and Fourier Transform Infrared (FTIR) Spectrosocpy Experiments}

An additional purification step of rAsc 15 was performed by size exclusion chromatography in 5 mM sodium phosphate buffer pH 6.8 using a Superdex 75 10/300 GL column (GE Healthcare Life Sciences) using an ÄKTA pure chromatography system (GE Healthcare Life Sciences). Amino acid composition and protein concentration were determined by amino acid analyses according to the PicoTagTM method (Waters, Milford, MA, USA) using a (HP) 1100 HPLC system (Hewlett-Packard, San Jose, CA, USA) equipped with a $3.9 \times 150 \mathrm{~mm}$ Nova-pak C18 column (Waters). The aggregation behavior was evaluated by dynamic light scattering (DLS) using a DLS 802 system (Viscotek Corp., Houston, TX, US). Data of 10 independently recorded measurements were evaluated using the OmniSize ${ }^{\mathrm{TM}}$ software (Viscotek Corp.) and displayed as mass weighted distribution of the hydrodynamic radius. For FTIR experiments, the spectra of rAsc $15(1000 \mu \mathrm{g} / \mathrm{mL})$ were recorded at a constant temperature $\left(25^{\circ} \mathrm{C}\right)$ using an AquaSpec transmission cell adapted to a Tensor II Confocheck FTIR system (Bruker Optics Inc., Billerica, MA, USA). The second derivative was calculated of the amide 1 band and the curve was smoothed by applying the Savitzky-Golay algorithm with 25 smoothing points. Spectra were vector-normalized, and baseline corrected (background signal of the buffer solution was subtracted). For the analysis of secondary structural elements, a Quant2 method provided by Confocheck (Bruker Optics Inc.) was used.

\subsection{Calcium and Magnesium-Binding Experiments and Circular Dichroism (CD) Spectroscopy}

ANS fluorescence experiments were performed in duplicates and recorded using an Infinite ${ }^{\circledR}$ 200 PRO Series plate reader (Tecan Trading AG, Switzerland) at room temperature and excitation wavelength of $370 \mathrm{~nm}$. rAsc 15 was prepared in $10 \mathrm{mM}$ Tris buffer at final concentration of $4 \mu \mathrm{M}$. $\mathrm{CaCl}_{2}$ or $\mathrm{MgCl}_{2}$ were prepared in serial two-fold dilutions starting from $400 \mathrm{mM}$ and incubated with rAsc 15 for $1 \mathrm{~h}$. ANS was added at final concentration of $50 \mu \mathrm{M}$. Fluorescence emission spectra were obtained between 400 and $600 \mathrm{~nm}$ and represented as area under the curve. $C D$ experiments were recorded to evaluate changes in secondary structure elements of rAsc 15 in presence of $\mathrm{CaCl}_{2}$ or $\mathrm{MgCl}_{2}$ at $20{ }^{\circ} \mathrm{C}$. CD spectra were recorded using a JASCO J-815 spectropolarimeter fitted with a PTC-423S Peltier type single position cell holder (Jasco, Tokyo, Japan), in $10 \mathrm{mM} \mathrm{K}_{2} \mathrm{HPO}_{4} / \mathrm{KH}_{2} \mathrm{PO}_{4}$. Samples were measured 
from 190-260 nm at resolution of $1 \mathrm{~nm}$ with $1 \mathrm{~nm}$ bandwidth and a scanning speed of $1 \mathrm{~nm} / \mathrm{s}$. Five spectra were averaged and background of the buffer solution was subtracted. Data were presented as mean residue molar ellipticity. Optimal ratios for CD experiments were selected from previous ANS assays where significant changes in fluorescence intensity were detected $(4 \mu \mathrm{M} \mathrm{rAsc} 15 / 50 \mathrm{mM} \mathrm{CaCl} 2$ or $4 \mu \mathrm{M} \mathrm{rAsc} 15 / 150 \mathrm{mM} \mathrm{MgCl}_{2}$ ). Final concentrations for CD experiments were: $100 \mu \mathrm{g} / \mathrm{mL}$ of rAsc 15 (corresponding to was $5.9 \mu \mathrm{M}$ ), $74 \mathrm{mM} \mathrm{CaCl}_{2}$ or $221 \mathrm{mM} \mathrm{MgCl}_{2}$, as needed.

\subsection{Modeling of Three-Dimensional Structure of Asc 15 and $\mathrm{Ca}^{2+}$ and $\mathrm{Mg}^{2+}$ Binding Sites}

A 3D-homology model of Asc 15 was based on the known NMR structure of Ani s 5. Asc 1 5 models were calculated with MODELLER [47] using all NMR-models from PDB entry 2MAR as templates. The best model was selected with the model scoring option of MAESTRO [48]. The figures of Asc 15 structure (ribbon and electrostatic surface representations) were done by UCSF Chimera [49]. Electrostatics was calculated with APBS [50]. For prediction of $\mathrm{Ca}^{2+}$ and $\mathrm{Mg}^{2+}$ binding sites, metal ion-binding (MIB) site prediction and docking server (http://bioinfo.cmu.edu.tw/MIB/) was used, which predicts metal binding sites using protein three-dimensional structure. MIB server was based on the local structural comparison between metal ions-binding residue templates that include residues coordinated to metal ions within $3.5 \AA$ and the 3D-homology model of Asc 15 [51] by using the fragment transformation method [52].

\subsection{Specific IgE}

Specific IgE antibody levels to Ascaris spp, D. pteronyssinus and B. tropicalis extracts were measured using ImmunoCAP system (Thermo Fisher Scientific), following the technical instructions of the manufacturer. Specific IgE levels equal to or greater than $0.35 \mathrm{kU} / \mathrm{A} / \mathrm{L}$ were considered positive. For indirect ELISA serum samples, conjugate dilutions and antigen concentrations were obtained by titration. Each well was coated with $1 \mu \mathrm{g}$ of antigen diluted in sodium carbonate/bicarbonate buffer. ELISA was performed as described before [20]. Cut-off value to define positive or negative IgE responses to $\mathrm{rAsc} 15$ was calculated as the mean optical density (OD) of 9 negative controls $+3 \mathrm{SD}$. The cut-off value for IgE anti-rAsc 15 was 0.145 . Sensitization was defined as a positive specific IgE result detected by ELISA or ImmunoCAP to any extract or to the recombinant allergen.

\subsection{Basophil Activation Test}

The basophil activation test was performed as recommended by the manufacturer of the assay Allergenicity Kit (Beckman Coulter, Inc. CA, USA) and measured by flow cytometry. Peripheral blood samples were collected from five rAsc 15 -sensitized individuals and one rAsc 15 -non sensitized control in endotoxin-free EDTA tubes. Aliquots $(50 \mu \mathrm{L})$ of the blood were incubated with $10 \mu \mathrm{L}$ of PBS (unstimulated control), $10 \mu \mathrm{L}$ of allergenicity positive control (Anti-IgE) or $10 \mu \mathrm{L}$ of serial dilutions of allergens (to final concentration of $0.1 \mu \mathrm{g} / \mathrm{mL}, 1 \mu \mathrm{g} / \mathrm{mL}$ and $10 \mu \mathrm{g} / \mathrm{mL}$ ) for $15 \mathrm{~min}$ at $37^{\circ} \mathrm{C}$. Basophils were gated based on the expression of CRTh2 marker and activation was assessed by detection of the activation marker CD203c using phycoerythrin-conjugated CD203c mAb 97A6 in a FACSAria ${ }^{\mathrm{TM}}$ III cytometer (BD Biosciences). Cytometry data analysis was undertaken using FlowJo V10 (Tree Star, Inc., Ashland, OR, USA). In each assay at least 500 basophils were counted. Allergen-induced upregulation of CD203c was expressed as the stimulation index (SI), calculated using mean fluorescence intensities (MFI) obtained with stimulated sample (MFI stim) divided by unstimulated sample (MFI control), SI $=$ MFI stim/MFI control. SI $\geq 2.0$ was considered positive $[53,54]$.

\subsection{Histamine Release}

Heparinized blood was drawn from samples using BD Vacutainers (Becton Dickinson, Franklin Lakes, NJ, USA). Basophil histamine release was induced by incubating $200 \mu \mathrm{L}$ of fresh blood with $200 \mu \mathrm{L}$ of serial concentrations (to final concentration of $0.01,0.1,1 \mu \mathrm{g} / \mathrm{mL}$ ) of $\mathrm{rAsc} 15$ or A. lumbricoides 
extract. Allergen dilution buffer and anti-human IgE positive control were used as described by the manufacturer (Histamine Release kit; IBL International GmbH, Hamburg, Germany). Histamine concentrations were quantified by ELISA (IBL International $\mathrm{GmbH}$, Hamburg, Germany). Total histamine release was determined in cells treated with hypotonic solution and regarded as $100 \%$ release. Spontaneous release was calculated in cells treated with allergen dilution buffer, and the result was subtracted from cells treated with allergens. Absorbance was measured at $450 \mathrm{~nm}$. Percent of allergen-induced release was calculated in relation to the total histamine release [9].

\subsection{Production of Antisera against rAsc 15, Antibody Determinations and PCA Model}

Polyclonal antisera to rAsc 15 were raised in 6 to 8-week-old female BALB/c mice (Instituto Nacional de Salud, INS, Bogotá, Colombia). Mice received intraperitoneal injections of rAsc $15(20 \mu \mathrm{g})$ suspension with aluminum hydroxide $2 \mathrm{mg}$ (Thermo Fisher Scientific) three times in a seven-day interval [55] and blood sampled 7 days after the last injection. Mice were also immunized with the HDM cross-reactive allergen tropomyosin (Asc 13) [9]. Solutions were prepared in PBS (Dulbecco's Phosphate-Buffered Saline, Thermo Fisher Scientific) before use and mixed thoroughly to ensure homogeneity. OVA-sensitized animals were the positive controls for these experiments [56] and PBS-treated mice the negative controls. Mice were kept under specific pathogen-free environment $\left(22^{\circ} \mathrm{C}, 50-60 \%\right.$ humidity, and 12-h light/dark cycle) and fed with standard pellet diet and drinking water ad libitum [45]. Animal experiments were performed in accordance with institutional protocols (University of Cartagena, Minutes 117, 13-03-2019). Antibody responses of animals were evaluated by ELISA. MaxisorpTM microtiter plates were coated with the antigens $(0.5 \mu \mathrm{g} /$ well $)$ by overnight incubation at $4{ }^{\circ} \mathrm{C}$ and washed 4 times with PBS $0.1 \%$ Tween 20 . Wells were then blocked with PBS $1 \%$ BSA for $3 \mathrm{~h}$ at room temperature. Plates were washed $(5 \mathrm{X})$ and incubated overnight with diluted plasma samples $(1: 10)$ at $4{ }^{\circ} \mathrm{C}$. After 5 washes, wells were incubated with biotin labeled anti-mouse IgE 1:1000 (Clone 2363, eBioscience), $1 \mathrm{~h}$ at room temperature (RT). After 5 washes, streptavidin-alkaline-phosphatase 1:4000 (Sigma-Aldrich, Saint Louis, MO, USA) was added and incubated an additional hour. $p$-nitrophenyl phosphate $(1 \mathrm{mg} / \mathrm{mL})$ was used as substrate solution. Optical densities were read at $405 \mathrm{~nm}$ in a spectrophotometer [55]. To increase the sensitivity of the IgE ELISA, IgG was depleted from serum by incubation with protein G sepharose [57]. The PCA model was performed as follows. Naive 6 to 8 -week-old female BALB/c mice were injected intradermally with $100 \mu \mathrm{L}$ of plasma from immunized mice into abdominal skin. Twenty-four hours later, each mouse was injected via the tail vein with $200 \mu \mathrm{L}$ containing $25 \mu \mathrm{g}$ of Ascaris molecules or PBS control, plus $0.5 \%$ Evan's Blue (PanReac AppliChem) dissolved in PBS. After $2 \mathrm{~h}$, the mice were euthanized. One square centimeter was cut from the pigmented area in each mouse. The removed skin was incubated with formamide, and then the extravasated Evans blue dye was extracted. The amount of dye absorbance at $620 \mathrm{~nm}$ was measured in a spectrophotometer (Spectra Max 250; Molecular Devices, Sunnyvale, CA, USA) [58].

\subsection{Statistics}

Analyses were conducted using SPSS version 20.0 (SPSS, Chicago, IL, USA) and GRAPHPAD PRISM version 5.01 for Windows (GraphPad Software, San Diego, CA, USA). IgE values of individual participants were not normally distributed; therefore, they were reported as median values and interquartile ranges (IC). Differences between proportions of subjects sensitized were analyzed by a Pearson chi-square test. The Mann-Whitney U-test was used for comparison of continuous variables as needed. For all analyses, $p$ values $<0.05$ (two tailed) were considered significant. For comparison of means of more than two groups, one-way ANOVA and Dunnett's multiple comparison test were used. In this case mean \pm standard error of the mean (SEM) was used for each group. 
Supplementary Materials: The following are available online at http://www.mdpi.com/1422-0067/21/24/9761/s1.

Author Contributions: Conceptualization, L.C., V.A., J.Z., L.A. and F.F.; methodology, V.A., M.M., J.Z., L.A., S.C., P.B., P.L., R.R. and G.A.; formal analysis, V.A., L.A., P.B., P.L., M.M., J.Z., F.F. and L.C.; investigation, V.A. and L.C.; resources, L.C., V.A., J.Z. and F.F.; data curation, V.A. and L.C.; writing-original draft preparation, V.A. and L.C.; writing-review and editing, V.A., M.M., J.Z., L.A., P.B., P.L., F.F., L.C.; visualization, V.A.; supervision, L.C.; project administration, L.C.; funding acquisition, L.C., V.A., J.Z. and F.F. All authors have read and agreed to the published version of the manuscript.

Funding: This work was supported by Minciencias (Grants 406-2011 and 803-2018), the University of Cartagena (Grant 02007-2018) and the University of Salzburg-Austria.

Acknowledgments: We thank all the research subjects for their voluntary participation in the study. V. Ahumada was awarded with a Ph.D. scholarship from the Ministry of Science, Technology and Innovation of the Colombian Government (Minciencias), an International Internship from the Austrian Agency for International Cooperation in Education \& Research (OeAD)-Austria, Centre for International Cooperation and Mobility (ICM)-Austria, and International Mobility Support by the University of Cartagena. We thank Dilia Mercado for her assistance in preparing A. lumbricoides extract.

Conflicts of Interest: The authors declare no conflict of interest.

$\begin{array}{ll}\text { Abbreviations } & \\ \text { IPTG } & \begin{array}{l}\text { isopropyl } \beta \text {-D-1-thiogalactopyranoside } \\ \text { phosphate buffered saline }\end{array} \\ \text { PBS } & \text { sodium dodecyl sulfate polyacrylamide gel electrophoresis } \\ \text { SDS-PAGE } & \text { Nanoscale liquid chromatography coupled to tandem mass spectrometry } \\ \text { nano-LC-MS/MS } & \text { Circular dichroism } \\ \text { CD } & \text { Dynamic light scattering } \\ \text { DLS } & \text { Enzyme-linked immunosorbent assay } \\ \text { ELISA } & \text { skin prick test } \\ \text { SPT } & \text { Escherichia coli } \\ \text { E. coli } & \text { Luria Bertani } \\ \text { LB } & \text { domain of unknown function } \\ \text { DUF } & \text { House dust mite } \\ \text { HDM } & \text { International Union of Immunological Societies } \\ \text { IUIS } & \end{array}$

\section{References}

1. Hagel, I.; Cabrera, M.; Hurtado, M.A.; Sanchez, P.; Puccio, F.; Di Prisco, M.C.; Palenque, M. Infection by Ascaris lumbricoides and bronchial hyper reactivity: An outstanding association in Venezuelan school children from endemic areas. Acta Trop. 2007, 103, 231-241. [CrossRef] [PubMed]

2. Moncayo, A.L.; Vaca, M.; Oviedo, G.; Workman, L.J.; Chico, M.E.; Platts-Mills, T.A.; Rodrigues, L.C.; Barreto, M.L.; Cooper, P.J. Effects of geohelminth infection and age on the associations between allergen-specific IgE, skin test reactivity and wheeze: A case-control study. Clin. Exp. Allergy J. Br. Soc. Allergy Clin. Immunol. 2013, 43, 60-72. [CrossRef] [PubMed]

3. Caraballo, L. The tropics, helminth infections and hygiene hypotheses. Expert Rev. Clin. Immunol. 2018, 14, 99-102. [CrossRef] [PubMed]

4. Weatherhead, J.E.; Porter, P.; Coffey, A.; Haydel, D.; Versteeg, L.; Zhan, B.; Gazzinelli Guimaraes, A.C.; Fujiwara, R.; Jaramillo, A.M.; Bottazzi, M.E.; et al. Ascaris Larval Infection and Lung Invasion Directly Induce Severe Allergic Airway Disease in Mice. Infect. Immun. 2018, 86. [CrossRef]

5. Acevedo, N.; Caraballo, L. IgE cross-reactivity between Ascaris lumbricoides and mite allergens: Possible influences on allergic sensitization and asthma. Parasite Immunol. 2011, 33, 309-321. [CrossRef]

6. Acevedo, N.; Sanchez, J.; Erler, A.; Mercado, D.; Briza, P.; Kennedy, M.; Fernandez, A.; Gutierrez, M.; Chua, K.Y.; Cheong, N.; et al. IgE cross-reactivity between Ascaris and domestic mite allergens: The role of tropomyosin and the nematode polyprotein ABA-1. Allergy 2009, 64, 1635-1643. [CrossRef]

7. Caraballo, L.; Acevedo, N.; Zakzuk, J. Ascariasis as a model to study the helminth/allergy relationships. Parasite Immunol. 2019, 41, e12595. [CrossRef] 
8. Acevedo, N.; Mohr, J.; Zakzuk, J.; Samonig, M.; Briza, P.; Erler, A.; Pomes, A.; Huber, C.G.; Ferreira, F.; Caraballo, L. Proteomic and immunochemical characterization of glutathione transferase as a new allergen of the nematode Ascaris lumbricoides. PLoS ONE 2013, 8, e78353. [CrossRef]

9. Acevedo, N.; Erler, A.; Briza, P.; Puccio, F.; Ferreira, F.; Caraballo, L. Allergenicity of Ascaris lumbricoides tropomyosin and IgE sensitization among asthmatic patients in a tropical environment. Int. Arch. Allergy Immunol. 2011, 154, 195-206. [CrossRef]

10. Caraballo, L.; Coronado, S. Parasite allergens. Mol. Immunol. 2018, 100, 113-119. [CrossRef]

11. Caraballo, L.; Acevedo, N. New Allergens of Relevance in Tropical Regions: The Impact of Ascaris lumbricoides Infections. World Allergy Organ. J. 2011, 4, 77-84. [CrossRef] [PubMed]

12. Zakzuk, J.; Acevedo, N.; Cifuentes, L.; Bornacelly, A.; Sanchez, J.; Ahumada, V.; Ring, J.; Ollert, M.; Caraballo, L. Early life IgE responses in children living in the tropics: A prospective analysis. Pediatr. Allergy Immunol. Off. Publ. Eur. Soc. Pediatric Allergy Immunol. 2013, 24, 788-797. [CrossRef] [PubMed]

13. Caraballo, L. Mite allergens. Expert Rev. Clin. Immunol. 2017, 13, 297-299. [CrossRef] [PubMed]

14. Garcia-Mayoral, M.F.; Trevino, M.A.; Perez-Pinar, T.; Caballero, M.L.; Knaute, T.; Umpierrez, A.; Bruix, M.; Rodriguez-Perez, R. Relationships between IgE/IgG4 epitopes, structure and function in Anisakis simplex Ani s 5, a member of the SXP/RAL-2 protein family. PLoS Negl. Trop. Dis. 2014, 8, e2735. [CrossRef]

15. Stigler, J.; Rief, M. Calcium-dependent folding of single calmodulin molecules. Proc. Natl. Acad. Sci. USA 2012, 109, 17814-17819. [CrossRef]

16. Gabellieri, E.; Strambini, G.B. ANS fluorescence detects widespread perturbations of protein tertiary structure in ice. Biophys. J. 2006, 90, 3239-3245. [CrossRef]

17. Kirberger, M.; Yang, J.J. Calcium-Binding Protein Site Types. In Encyclopedia of Metalloproteins; Kretsinger, R.H., Uversky, V.N., Permyakov, E.A., Eds.; Springer: New York, NY, USA, 2013; pp. 511-521. [CrossRef]

18. Zheng, H.; Cooper, D.R.; Porebski, P.J.; Shabalin, I.G.; Handing, K.B.; Minor, W. CheckMyMetal: A macromolecular metal-binding validation tool. Acta Crystallogr. Sect. D Struct. Biol. 2017, 73, 223-233. [CrossRef]

19. Caraballo, L.; Zakzuk, J.; Lee, B.W.; Acevedo, N.; Soh, J.Y.; Sanchez-Borges, M.; Hossny, E.; Garcia, E.; Rosario, N.; Ansotegui, I.; et al. Particularities of allergy in the Tropics. World Allergy Organ. J. 2016, 9, 20. [CrossRef]

20. Ahumada, V.; Garcia, E.; Dennis, R.; Rojas, M.X.; Rondon, M.A.; Perez, A.; Penaranda, A.; Barragan, A.M.; Jimenez, S.; Kennedy, M.W.; et al. IgE responses to Ascaris and mite tropomyosins are risk factors for asthma. Clin. Exp. Allergy J. Br. Soc. Allergy Clin. Immunol. 2015, 45, 1189-1200. [CrossRef]

21. Zakzuk, J.; Mercado, D.; Bornacelly, A.; Sanchez, J.; Ahumada, V.; Acevedo, N.; Caraballo, L. Hygienic conditions influence sensitization to Blomia tropicalis allergenic components: Results from the FRAAT birth cohort. Pediatr. Allergy Immunol. Off. Publ. Eur. Soc. Pediatr. Allergy Immunol. 2019, 30, 172-178. [CrossRef]

22. Buendia, E.; Zakzuk, J.; Mercado, D.; Alvarez, A.; Caraballo, L. The IgE response to Ascaris molecular components is associated with clinical indicators of asthma severity. World Allergy Organ. J. 2015, 8, 8. [CrossRef] [PubMed]

23. Tsuji, N.; Suzuki, K.; Kasuga-Aoki, H.; Matsumoto, Y.; Arakawa, T.; Ishiwata, K.; Isobe, T. Intranasal immunization with recombinant Ascaris suum 14-kilodalton antigen coupled with cholera toxin B subunit induces protective immunity to A. suum infection in mice. Infect. Immun. 2001, 69, 7285-7292. [CrossRef] [PubMed]

24. Wei, J.; Versteeg, L.; Liu, Z.; Keegan, B.; Gazzinelli-Guimaraes, A.C.; Fujiwara, R.T.; Briggs, N.; Jones, K.M.; Strych, U.; Beaumier, C.M.; et al. Yeast-expressed recombinant As16 protects mice against Ascaris suum infection through induction of a Th2-skewed immune response. PLoS Negl. Trop. Dis. 2017, 11, e0005769. [CrossRef] [PubMed]

25. Fujiwara, R.T.; Zhan, B.; Mendez, S.; Loukas, A.; Bueno, L.L.; Wang, Y.; Plieskatt, J.; Oksov, Y.; Lustigman, S.; Bottazzi, M.E.; et al. Reduction of worm fecundity and canine host blood loss mediates protection against hookworm infection elicited by vaccination with recombinant Ac-16. Clin. Vaccine Immunol. 2007, 14, 281-287. [CrossRef]

26. Rao, K.V.; Eswaran, M.; Ravi, V.; Gnanasekhar, B.; Narayanan, R.B.; Kaliraj, P.; Jayaraman, K.; Marson, A.; Raghavan, N.; Scott, A.L. The Wuchereria bancrofti orthologue of Brugia malayi SXP1 and the diagnosis of bancroftian filariasis. Mol. Biochem. Parasitol. 2000, 107, 71-80. [CrossRef] 
27. Klion, A.D.; Vijaykumar, A.; Oei, T.; Martin, B.; Nutman, T.B. Serum immunoglobulin G4 antibodies to the recombinant antigen, Ll-SXP-1, are highly specific for Loa loa infection. J. Infect. Dis. 2003, 187, 128-133. [CrossRef]

28. Kobayashi, Y.; Ishizaki, S.; Shimakura, K.; Nagashima, Y.; Shiomi, K. Molecular cloning and expression of two new allergens from Anisakis simplex. Parasitol. Res. 2007, 100, 1233-1241. [CrossRef]

29. Rodriguez-Perez, R.; Moneo, I.; Rodriguez-Mahillo, A.; Caballero, M.L. Cloning and expression of Ani s 9, a new Anisakis simplex allergen. Mol. Biochem. Parasitol. 2008, 159, 92-97. [CrossRef]

30. Kobayashi, Y.; Shimakura, K.; Ishizaki, S.; Nagashima, Y.; Shiomi, K. Purification and cDNA cloning of a new heat-stable allergen from Anisakis simplex. Mol. Biochem. Parasitol. 2007, 155, 138-145. [CrossRef]

31. Finn, B.E.; Forsen, S. The evolving model of calmodulin structure, function and activation. Structure 1995, 3, 7-11. [CrossRef]

32. Yamniuk, A.P.; Vogel, H.J. Calmodulin's flexibility allows for promiscuity in its interactions with target proteins and peptides. Mol. Biotechnol. 2004, 27, 33-57. [CrossRef]

33. Yap, K.L.; Kim, J.; Truong, K.; Sherman, M.; Yuan, T.; Ikura, M. Calmodulin target database. J. Struct. Funct. Genom. 2000, 1, 8-14. [CrossRef] [PubMed]

34. Schneider, L.K.; Einsle, O. Role of Calcium in Secondary Structure Stabilization during Maturation of Nitrous Oxide Reductase. Biochemistry 2016, 55, 1433-1440. [CrossRef] [PubMed]

35. Dubiela, P.; Aina, R.; Polak, D.; Geiselhart, S.; Humeniuk, P.; Bohle, B.; Alessandri, S.; Del Conte, R.; Cantini, F.; Borowski, T.; et al. Enhanced Pru p 3 IgE-binding activity by selective free fatty acid-interaction. J. Allergy Clin. Immunol. 2017, 140, 1728-1731.e1710. [CrossRef]

36. Dubiela, P.; Del Conte, R.; Cantini, F.; Borowski, T.; Aina, R.; Radauer, C.; Bublin, M.; Hoffmann-Sommergruber, K.; Alessandri, S. Impact of lipid binding on the tertiary structure and allergenic potential of Jug r 3, the non-specific lipid transfer protein from walnut. Sci. Rep. 2019, 9, 2007. [CrossRef]

37. Engel, E.; Richter, K.; Obermeyer, G.; Briza, P.; Kungl, A.J.; Simon, B.; Auer, M.; Ebner, C.; Rheinberger, H.J.; Breitenbach, M.; et al. Immunological and biological properties of Bet $\mathrm{v} 4$, a novel birch pollen allergen with two EF-hand calcium-binding domains. J. Biol. Chem. 1997, 272, 28630-28637. [CrossRef]

38. Silva, M.T.; Costa, V.A.; Pereira, T.G.; Sales, I.R.; Silva, S.F.; Maciel, M.A.; Malagueño, E.; Souza, V.M. Severity of atopic dermatitis and Ascaris lumbricoides infection: An evaluation of CCR4+ and CXCR3+ helper T cell frequency. Rev. Soc. Bras. Med. Trop. 2012, 45, 761-763. [CrossRef]

39. Zakzuk, J.; Casadiego, S.; Mercado, A.; Alvis-Guzman, N.; Caraballo, L. Ascaris lumbricoides infection induces both, reduction and increase of asthma symptoms in a rural community. Acta Trop. 2018, 187, 1-4. [CrossRef]

40. Matsumoto, Y.; Suzuki, S.; Nozoye, T.; Yamakawa, T.; Takashima, Y.; Arakawa, T.; Tsuji, N.; Takaiwa, F.; Hayashi, Y. Oral immunogenicity and protective efficacy in mice of transgenic rice plants producing a vaccine candidate antigen (As16) of Ascaris suum fused with cholera toxin B subunit. Transgenic Res. 2009, 18, 185-192. [CrossRef]

41. Tsuji, N.; Miyoshi, T.; Islam, M.K.; Isobe, T.; Yoshihara, S.; Arakawa, T.; Matsumoto, Y.; Yokomizo, Y. Recombinant Ascaris 16-Kilodalton protein-induced protection against Ascaris suum larval migration after intranasal vaccination in pigs. J. Infect. Dis. 2004, 190, 1812-1820. [CrossRef]

42. Diemert, D.J.; Pinto, A.G.; Freire, J.; Jariwala, A.; Santiago, H.; Hamilton, R.G.; Periago, M.V.; Loukas, A.; Tribolet, L.; Mulvenna, J.; et al. Generalized urticaria induced by the Na-ASP-2 hookworm vaccine: Implications for the development of vaccines against helminths. J. Allergy Clin. Immunol. 2012, 130, 169-176 e166. [CrossRef] [PubMed]

43. Acevedo, N.; Sanchez, J.; Zakzuk, J.; Bornacelly, A.; Quiroz, C.; Alvarez, A.; Puello, M.; Mendoza, K.; Martinez, D.; Mercado, D.; et al. Particular characteristics of allergic symptoms in tropical environments: Follow up to 24 months in the FRAAT birth cohort study. BMC Pulm. Med. 2012, 12, 13. [CrossRef]

44. Dennis, R.J.; Caraballo, L.; Garcia, E.; Rojas, M.X.; Rondon, M.A.; Perez, A.; Aristizabal, G.; Penaranda, A.; Barragan, A.M.; Ahumada, V.; et al. Prevalence of asthma and other allergic conditions in Colombia 2009-2010: A cross-sectional study. BMC Pulm. Med. 2012, 12, 17. [CrossRef] [PubMed]

45. Coronado, S.; Barrios, L.; Zakzuk, J.; Regino, R.; Ahumada, V.; Franco, L.; Ocampo, Y.; Caraballo, L. A recombinant cystatin from Ascaris lumbricoides attenuates inflammation of DSS-induced colitis. Parasite Immunol. 2017, 39. [CrossRef] 
46. Wolf, M.; Twaroch, T.E.; Huber, S.; Reithofer, M.; Steiner, M.; Aglas, L.; Hauser, M.; Aloisi, I.; Asam, C.; Hofer, H.; et al. Amb a 1 isoforms: Unequal siblings with distinct immunological features. Allergy 2017, 72, 1874-1882. [CrossRef]

47. Webb, B.; Sali, A. Comparative Protein Structure Modeling Using MODELLER. Curr. Protoc. Bioinform. 2016, 54, 5.6.1-5.6.37. [CrossRef]

48. Laimer, J.; Hofer, H.; Fritz, M.; Wegenkittl, S.; Lackner, P. MAESTRO-multi agent stability prediction upon point mutations. BMC Bioinform. 2015, 16, 116. [CrossRef]

49. Pettersen, E.F.; Goddard, T.D.; Huang, C.C.; Couch, G.S.; Greenblatt, D.M.; Meng, E.C.; Ferrin, T.E. UCSF Chimera-a visualization system for exploratory research and analysis. J. Comput. Chem. 2004, 25, 1605-1612. [CrossRef]

50. Jurrus, E.; Engel, D.; Star, K.; Monson, K.; Brandi, J.; Felberg, L.E.; Brookes, D.H.; Wilson, L.; Chen, J.; Liles, K.; et al. Improvements to the APBS biomolecular solvation software suite. Protein Sci. A Publ. Protein Soc. 2018, 27, 112-128. [CrossRef]

51. Kumar, R.; Breindel, C.; Saraswat, D.; Cullen, P.J.; Edgerton, M. Candida albicans Sap6 amyloid regions function in cellular aggregation and zinc binding, and contribute to zinc acquisition. Sci. Rep. 2017, 7, 2908. [CrossRef]

52. Lin, Y.F.; Cheng, C.W.; Shih, C.S.; Hwang, J.K.; Yu, C.S.; Lu, C.H. MIB: Metal Ion-Binding Site Prediction and Docking Server. J. Chem. Inf. Modeling 2016, 56, 2287-2291. [CrossRef]

53. MacGlashan, D.W., Jr. Basophil activation testing. J. Allergy Clin. Immunol. 2013, 132, 777-787. [CrossRef] [PubMed]

54. Martinez, D.; Munera, M.; Cantillo, J.F.; Wortmann, J.; Zakzuk, J.; Keller, W.; Caraballo, L.; Puerta, L. An Engineered Hybrid Protein from Dermatophagoides pteronyssinus Allergens Shows Hypoallergenicity. Int. J. Mol. Sci. 2019, 20, 3025. [CrossRef]

55. Zakzuk, J.; Benedetti, I.; Fernandez-Caldas, E.; Caraballo, L. The influence of chitin on the immune response to the house dust mite allergen Blo T 12. Int. Arch. Allergy Immunol. 2014, 163, 119-129. [CrossRef] [PubMed]

56. Chen, C.; Sun, N.; Li, Y.; Jia, X. A BALB/c mouse model for assessing the potential allergenicity of proteins: Comparison of allergen dose, sensitization frequency, timepoint and sex. Food Chem. Toxicol. Int. J. Publ. Br. Ind. Biol. Res. Assoc. 2013, 62, 41-47. [CrossRef] [PubMed]

57. Lehrer, S.B.; Reish, R.; Fernandes, J.; Gaudry, P.; Dai, G.; Reese, G. Enhancement of murine IgE antibody detection by IgG removal. J. Immunol. Methods 2004, 284, 1-6. [CrossRef] [PubMed]

58. Evans, H.; Killoran, K.E.; Mitre, E. Measuring local anaphylaxis in mice. J. Vis. Exp. 2014, 14, e52005. [CrossRef]

Publisher's Note: MDPI stays neutral with regard to jurisdictional claims in published maps and institutional affiliations.

(C) 2020 by the authors. Licensee MDPI, Basel, Switzerland. This article is an open access article distributed under the terms and conditions of the Creative Commons Attribution (CC BY) license (http://creativecommons.org/licenses/by/4.0/). 